\title{
Várnagy Péter
}

\section{JOHN HENRY NEWMAN SZEREPE A KÖZNEVELÉSBEN}

\begin{abstract}
Absztrakt
Jelen cikkem megírásának egyik ösztönzője, hogy Newman személyével már a 90-es évek elején megismerkedtem, amikor még a PTE BTK Neveléstudományi Tanszékén Newman pedagógiájáról először hallottam, amely érdeklődésem origójaként határozható meg. Vonzódásom a témához fokozódott, így igyekeztem az elmúlt évek során minél több forrást felkutatni magyar és angol nyelven egyaránt, amely Newman életútjához, de főként a nevelési tevékenységéhez kapcsolódik. Ez vezetett a 2014-ben megjelent könyvemhez (Várnagy, 2014), amely alapvetően a felsőoktatáshoz kötődik. A mostani tanulmányom pedig Newman köznevelési tevékenységeinek meghatározó vonatkozásait ragadja meg. A téma feldolgozásához elsősorban az idegen nyelvű szakirodalom és források elemzésre, továbbá interpretálásra fókuszáltam, amelyhez jó alapot nyújtottak Newman levelezésének és naplójának könyvekbe foglalt kötetei.

Túlzás lenne azt állítani, hogy Newman meghatározóan köznevelési szakember lett volna, de egyértelműen maradandó nyomot hagyott pedagógiai gondolataival és tevékenységével e területen is.
\end{abstract}

Kulcsszavak: Newman; köznevelés; iskola

\section{Bevezető}

John Henry Newman Londonban született 1801-ben. Hat testvére között ő volt a legidősebb. Apja jól szituált bankár volt, aki hamar csődbe került. Édesanyja francia protestáns (hugenotta) családi gyökerei ellenére Newman családja az anglikán vallás világszemlélete alapján élt, meglehetősen szűkös körülmények között. Serdülő korában a matematika, klasszikus nyelvek, filozófia, zene egyaránt érdekelték. Mégis teológiára jelentkezett az egyetemen (Conzemius, 1991).

Az anglikán egyház papjává szentelték 1825-ben. Közel két évtizedes megfontolásokkal teli életszakaszt követően 1845-ben katolizált. Ezután Rómában tanult és itt lett szerzetes-pap az oratóriánusoknál. Konvertitaként tért vissza Angliába 1840-es évek végén (Vértesaljai, 2019).

Megalapozott hírnevet szerzett egyetemi oktatóként. A bíboros XIX. század eleji élete és alkotói munkássága jól ismert, továbbá áttérése a Római Katolikus Egyházba talán még inkább dokumentált. Szent emberként tartják számon, aki életével mély hatást gyakorolt az angliai katolicizmusra. Az Ír Katolikus Egyetemre történő rektori kinevezésének, amelynek alapításában is részt vett, köszönhetjük „The Idea of a University” (Az egyetem eszméje) c. művét. 1878-ban Newman visszatért Oxfordba, hogy tiszteletbeli munkatárásává váljon a Trinity College-nak, amelynek korábban növedéke volt. XIII. Leó pápa 1879ben bíborossá nevezte ki 11 évvel később, 1890-ben hunyt el Birminghamben. 
Az előbbiek köztudott tények Newman életéről, de az kevésbé ismert hazánkban, hogy létrehozott (1859) és több, mint harminc évig működtetett egy fiúiskolát Edgbastonban (egy elővárosi terület Birminghamnek), amelynek 1920-as évek elején Reading közelébe kellett költöznie, de átélve a II. világháború viszontagságait is a mai napig működik, és 2020 szeptemberétől koedukált intézményként már lányokat is fogad (The Oratory School, dátum nélk.).

A bevezető sorok zárása előtt, röviden a módszeradaptációról. A szakirodalmi és történeti tartalomelemzésem - tekintettel arra, hogy a magyarul hozzáférhető bibliográfia viszonylag szűkös - elsősorban angol nyelvű forrásokon nyugszik. Ezek között is meghatározó jelentőséggel bírnak Newman autobiografikus írásai („The letters and diaries of John Henry Newman”, azaz „John Henry Newman levelei és naplói”). „Művei 37 kötetet töltenek meg, ... és szinte beláthatatlan tömege a leveleknek, amelyek igen nagy része a legmagasabb tudományos és irodalmi igénnyel, sokszor pedig megrendítő őszinteséggel, a keresztény önérzetnek és alázatnak a nagy szentekre jellemző egységével készült." (Sík, 1955, p. 344)

\section{Newman iskolája}

Pontatlan lenne azt állítani, hogy Newman elsősorban köznevelési szakember lett volna, de egyértelmúen maradandó nyomot hagyott pedagógiai gondolataival, ahogy ez kitűnik „Az egyetem eszméje” c. művéből is. Kevés eredeti elképzelést fogalmazott meg a középiskolai oktatással kapcsolatban. Ezen a szinten nem volt oktatási teoretikus, de nagyon sikeresen tanított. Newman tisztában volt a fiúk számára biztosított katolikus oktatás jelentőségével, különösen mivel sokan közülük konvertiták fiai voltak, és látta annak szükségességét, hogy ez az oktatás az általános műveltség megszerzésére irányuljon és tudományos alapú legyen. Végeredményként egy remek és nagyon sikeres iskolát alapított egy jelentős ellenzékkel szemben, akik nagyrészt a saját egyházának a tagjai voltak. Két fő irányvonal jellemzi Newman oktatási tevékenységét az 1845-ös konverzióját követő 20 éves időszakban, egyrészt a liberális oktatás iránti aggodalma, másrészt a vallásos nevelés aránya a fiatalok oktatásában. Ami az előbbit illeti, Newman úgy vélte, hogy „liberális oktatás nem kereszténnyé, hanem úriemberré tesz ... A liberális oktatás önmagában nézve egyszerűen az értelem művelése, és tárgya nem több vagy kevesebb, mint intellektuális kiválóság ..." (Newmant idézi Stockley, 1922, pp. 303-311)

A katolikus oktatás iránti felelősségérzet Newman két aggodalmából fakad. Az egyik, hogy a vallást helyezi a hatékony oktatási rendszer központjába, a másik pedig, hogy Angliában a XIX. század első évtizedeiben a szekularizmus növekvő hulláma volt jelen az oktatásban. Newman a teológiát határozta meg az oktatás alapjaként: „Az egyetemnek ... már a megnevezésénél fogva is egyetemes ismereteket kell tanítania; a teológia biztosan egy tudományág: hogy lehet akkor tanítani az összes diszciplínát, ha egyet mégis kizárunk, amely legalább annyira fontos, mint bármelyik másik?" (Newman \& Svaglic, 1982, pp. 1415)

Newman elsősorban a felsőoktatással foglalkozott, de amit ezzel összefüggésben írt, ugyanúgy alkalmazható a fiatalabbak oktatásával kapcsolatos elképzeléseire is. Newman 
aggodalommal tekintett az angol oktatásra nehezedő első nagyobb szekularista nyomásra. Ennek bizonyítékai között említhetjük a „Society for the Diffusion of Useful Knowledge” (Hasznos Ismereteket Terjesztő Társaság), továbbá a „University College London” 1826-os alapítását, amelyekben meghatározó szerepe volt a skót Lord Henry Brougham bárónak (Ashton, 2008). Az utóbbi alternatívájává kívánt válni az anglikán oxfordi és cambridge-i egyetemeknek, és közismerten hangsúlyozta a világi, nem pedig a vallási ismeretek átadását. Newman aggodalma az egyre növekvő szekularizmus miatt abból a meggyőződésből fakadt, hogy a hit központi szerepet játszik az oktatásban. Célja az volt, hogy az oktatást vallásos szellemiség hassa át.

Newman minden bizonnyal korának a legtehetségesebb angol katolikusa volt, és valószínűleg egyik legjobban képzett személyisége is. Ennélfogva természetes, hogy őt bízták meg a tervezett írországi katolikus egyetem alapításával. Newman kinevezésére hivatkozva, talán meglehetősen komolytalanul azt mondta: „... megértetni az írekkel, hogy mi az oktatás, az egyetem, és hogy kötelességük egy olyan egyetem létrehozása, amelynek én lennék a rektora." (Newmant idézi Culler, 1955, p. 140) E megbízatása 1851-ben kezdődött. Az állandó utazása Írországba és vissza, valamint betöltött pozíciójának az ellenzése megbosszulta magát, így 1857-re elfáradt és kész volt feladni. Ez az írországi munka megerősítette abban a meggyőződésében, hogy a katolikus oktatás sajnálatos módon semmilyen szinten sem megfelelő. Ekkor merült fel először egy új katolikus fiúiskola létrehozásának gondolata. Newman már hosszabb ideje meg volt győződve egy ilyen intézmény szükségességéről.

A XIX. század közepére nyilvánvaló volt, hogy a katolikus oktatás előtt álló válságot már nem lehet elkerülni. A katolikus fiúk számára létező legkiemelkedőbb iskolák, Stoneyhurst, Oscott és Downside, nem voltak megfelelő színvonalúak a tanítás és a nevelés terén sem. Ezek az intézmények túlzsúfoltak voltak, viszont jelentős igény mutatkozott a szolgáltatásaikra a művelt konvertiták számának növekedése miatt. A szülők rájöttek, hogy minőségi oktatás nélkül gyermekeiknek alig van esélyük a fejlődésre. Newman 1858-ban tért vissza Birminghambe, ekkor szakadt meg a kapcsolata a katolikus egyetemmel. Itt szembesült azokkal a különböző helyekről érkező kérésekkel, amelyek egy fiúiskola létesítésének az igényét fogalmazták meg. Ennek teljesítését nem tudta, és nem is akarta megtagadni, mivel ez egybeesett saját meggyőződésével, így 1859-ben létrejött a Néri Szent Fülöpről elnevezett oratóriumi iskola. Természetesen voltak ellenlábasok is, akik azt állították, hogy Newman nem képes a fiúk vallási és erkölcsi nevelésének felügyeletére. Mint minden új iskola alapításakor itt is adódtak nehézségek, így az első évek szorongással teltek Newman számára. Végül, ahogy az iskola ismertebbé vált, megjelentek az idősebb fiúk is, akiknek a jelleme és magatartása támadhatatlan volt. Newman később feljegyezte, hogy létrehozott egy iskolát a protestáns intézmények mintájára, azokkal a módosításokkal, amelyeket a katolikus nevelés megkíván (Tristram, 1957).

Különösen Ullathorne püspök és Wiseman bíboros részéről mutatkozott erőteljes ellenállás Newman vállalkozásával szemben. William Bernard Ullathorne püspök hűvösen fogadta a javaslatot, és mindenféle problémát vetett fel. Kétségei voltak Newman fegyelmezési képességeivel kapcsolatban. Newman Edward Bellasisnak, az egyik legkövetkezetesebb támogatójának írta: „Örülök, hogy a püspök kifejezte önnek valódi kételyeit ... ha 
azt gondolja, hogy a gyakorlatban nem vagyok jó nevelő, akkor teljesen egyetértek vele. A legkevésbé vagyok rátermett iskolaigazgató vagy dékán, mint ahogy lovas vagy sakkozó sem. De ez nem gátolja azt, hogy érezzem a fiúk szigorú fegyelmezésének szükségességét" (Newman, 1968, p. 314).

Wiseman bíboros ellenérzése komolyabb volt az erős római befolyása miatt. Nyilvánvaló, hogy Wiseman nem szerette Newmant, értelmiségiként és konvertitaként nehezteltek rá és nem bíztak benne. Wiseman ellenezte az egész iskolaprojektet, aggodalmának adott hangot Bellasis és Acton felé, akik támogatták a projektet. Aggályai az „elnökre”, a vallási oktatásra, a fegyelemre, a tanulmányokra és az általános vezetésre vonatkoztak. Newman válaszai nem elégítették ki Wiseman-t, de fel sem dühítették. Mindenesetre Newman 1858 húsvét hétfőjén számolhatott be arról, hogy a bíboros mossa kezeit az iskola ügyében, és ezért a kizárólagos felelősség Ullathorne püspököt terheli (Newman, 1968).

A lejárató kampány különösen bántó volt Newman számára, mert személyesen ellene irányult, és értelemszerűen ártott az iskolának. Kétségtelen, hogy Newmant, mint egy érzékeny embert nagyon bántották az ilyen pletykák, mivel nehéz volt rá reagálnia. Newman elismerte: „... a barátaim mondhatják, hogy az iskola érdekében köteles vagyok válaszolni rájuk. Nem ezt akarom tenni: először is azért, mert hosszú távon a hamisság cáfolja önmagát; másodszor mert, álláspontom visszavetülne azokra, akik a vádakat szórják ..." (Ward, 1913, p. 455)

A másik akadály, amelyet Newmannek és támogatóinak le kellett küzdeniük, hogy a már létező iskolákkal folytatott verseny ne eméssze fel erőiket, és ne vezessen intézménybezárásokhoz. Newman maga, és a jómódú támogatói is a végsőkig kitartottak. Ennek eredményeként 1858 decemberében Newman összeállította az iskola tájékoztatójának a tervezetét.

Az iskola létrehozását először azok a konvertiták javasolták, akik aggódtak fiaik katolikus szellemű megfelelő és jó oktatásáért. A csoport nem kevesebb, mint 32 emberből állt, és számos kiváló férfi volt köztük, mint Norfolk hercege, Compden és Fielding vikomtok, Lord Charles Thynne, William Dodsworth és Henry Wilberforce. Javaslatukat először Newman-nek 1858 január elején tették meg. Ballais így fogalmazott: „A tény az, hogy mindannyian egyetértettünk abban, hogy ön az a személy, akinek irányítása alatt kell állnia az iskolának." (Newman, 1968, p. 252)

Newman válasza biztató volt, de hangsúlyozta, hogy a megbízást csak akkor vállalja, ha Ullathorne püspök nem ellenzi az iskolaalapítást. Ullathorne, akinek az ötlet nem volt teljesen új, kezdetben támogatta, mivel a meglévő katolikus iskolák megteltek, és volt igény egy másikra is. 1858 januárja és februárja nagyon mozgalmasan telt. A kezdeti tervezésben 20 fiú szerepelt, akik 70 fontot fizettek volna, néhányan egy kicsit magasabb összeget. Az egyik oratorista, Fr. Darnell napi négy óra önkéntes szolgálatot vállalt. Newman egy „jó házat keresett a közelben kerttel és éves 120 fontos bérleti díjjal." Így Newman 1858. április 23-án ezt írhatta Bellaisnak: „Úgy döntöttünk, hogy elindítjuk az iskolát...” (Newman, 1968, p. 330). Newman részletesen ismertette a várható kiadásokat és bevételeket, a deficit eshetőségét, valamint a tennivalókat abban a valószínűtlen helyzetben, ha az iskola profitot termel. A leendő diákok szüleivel is levelezett, de végül csak hét fiú kezdte meg 
tanulmányait, akik mind felső- vagy középosztályból származó konvertita szülők gyermekei voltak. Az egyik legérdekesebb megjegyzés W. J. O'Neill Daunt fiához fűződik, akit édesapja a következőképpen írt le: „Rendkívül intelligens, vad, lusta...; nagyon erős katolikus érzéseket mutató...; nagyon hajlamos a mókára és az utánzásra; összeségében benne rejlik a nagyon jó vagy nagyon rossz megalkotása." (Newman, 1968, p. 315)

Amikor az iskola 1859. május 1-jén hét tanulóval megnyitotta kapuit, bár az igazgató Fr. Darnell volt, a tervezés nagy része mégis Newmanre hárult, mert reputációja és szövetsége a befolyásos támogatóival nagyon erősnek bizonyult. Várható volt, hogy növekszik az iskolába való beiratkozások száma, amely be is következett, a kezdeti hét fős csoport fél év alatt tizenkettőre, majd két évvel később hetvenre gyarapodott. Newman számára az egyik fő probléma az volt, hogy miként lehet befogadni az egyre növekvő létszámú diákságot. A támogatások különböző forrásokból származtak pl. Norfolk hercegnője 500 fontot adott 1860 márciusában. Newman az 1860. május 30-án kelt memorandumában ezt írta: „Úgy esett, hogy épp most véletlenül különböző forrásokból az ölünkbe hullott 4400 font vagy még annál is nagyobb összeg... Javaslom, hogy mindezt (vagy legalább 3400 fontot) az iskola materiális (és morális) megszilárdítására használjuk fel." (Newman, 1969, pp. 348-350)

A tervezett átalakítások magukba foglalták „Fr. Ambrose házainak” a felszerelését a fiúk befogadására, tantermek, személyzeti lakások és irodák biztosítását, valamint a templom bővítését és renoválását. Augusztus végére megszereztek 8 hold földet, amely egy körbe kerített területként a fiúk ,játszótereként” szolgált, de tanterem nem épült. Newman 1861 februárjában még fontolóra vett különböző javaslatokat. Az egyik körülbelül 900, míg a másik 4000 font körüli összegre rúgott. Határozatlansága egyértelműen az iskola még mindig megoldatlan pénzügyi helyzetének volt köszönhető. Newmannek egész életében visszatérő problémát okoztak az iskola pénzügyei. Úgy érezte, hogy másoknak - a gazdag katolikusoknak, és mindenekelőtt az iskolában tanulók szüleinek nagylelkűbbeknek kellett volna lenniük. Newman ezt egészen egyértelművé tette egy 1861. február 5-én kelt feljegyzésben (Newman, 1969). A szülők - ahogy azt sejtette nem tettek eleget anyagi kötelezettségeiknek, így csak 9000 fontot lehetett költeni a projektre. Nem meglepő, hogy Newman rövidesen emelte a tandíjat.

Newman e kudarcok ellenére és számos egyéb viszontagság mellett, nagyon sok mindennel elégedett lehetett. Amikor az első tanév 1860. július 20-án véget ért, az iskola egyértelműen egy működő egység volt stabil tantestülettel és diáklétszámmal. Saját épületeik voltak, bár ezek fejlesztésre szorultak.

A pénzügyek mellett a szülőkkel való kapcsolattartás volt a Newmanre háruló másik feladat, talán azért, mert sokukat személyesen vagy hírből ismerte. A legtöbb esetben Newman csak kellemes kötelességének tett eleget, amikor beszámolt arról, hogy a fiúk beilleszkedése és tanulmányaik folytatása zökkenőmentesen alakul, ahogy ez a Norfolki hercegnő fiának az esetében is történt (Newman, 1970). Időnként szigorúbban kellett fellépnie, például amikor 1862 júniusában írt levelében Sir John Actont emlékeztetnie kellett unokaöccse még kifizetetlen tandíjára (Newman, 1970). Egy másik visszatérő téma az volt, hogy tanácsot adtak azoknak a fiúknak, akik hivatást éreztek a papság iránt (vagy azt képzelték). Időnként általános leveleket küldtek minden szülőnek. Ezek leggyakoribb 
szükségességét a kanyarójárványok vagy más gyermekkori betegségek okozták, amelyek manapság nem okoznak nagy aggodalmat, de akkor súlyosnak számítottak. 1874 áprilisában Newman kénytelen volt írni a szülőknek, hogy a kijelölt időpontban ne küldjék vissza a gyermekeiket, mert kanyarójárvány után fertőtleníteni kell az iskola helyiségeit. Newman nyilvánvalóan kissé megterhelőnek érezte a levélírást. Egy barátjának, Miss Giberne-nek, - akivel rendszeresen levelezett, - így írt: „60 levelet kellett írnom a szülőknek, és ez minden félév végén előfordul." (Newman, 1970, p. 238)

Newman számára az egyik legélvezetesebb feladat az évenként esedékes iskolai színdarab megvalósítása volt, amelyet általában évente kétszer-háromszor adtak elő az ún. Szülők Napján. A diákok legtöbb esetben ókori római műveket adtak elő. Az első alkalommal, 1865-ben egy vígjátékot mutattak be. Az első előadásra Newman válogatta és készítette fel a fiúkat, amelyre a védőszentjük - Szent Fülöp - napján került sor. A színdarabok előadása ezután évenként visszatérő hagyománnyá vált. Ezt követte az ünnepi szentmise, majd ebéd, délután pedig krikettet és krokettet játszottak. Newman maga választotta és rendezte a színműveket (pl. Terentius: Phormio, Plautus: Aulularia stb.), és természetesen jelen is volt az előadásokon egészen 1890-ben bekövetkezett haláláig. Időnként cenzúrázta a színdarabokat, vagy saját adaptációt írt belőlük.

A színdarabokra való felkészülés mellett Newman a latin, illetve később a zene tanítása során, valamint az oktatásszervezésben játszott általános szerepe kapcsán került kapcsolatba a fiúkkal. Szükség esetén általános útmutatást is adott. Például amikor a norfolki herceg egy diákcsoport csatlakozását javasolta az angol ifjúsági küldöttséghez, akik IX. Piusz pápaságának 25. évfordulója ünneplésére készülődtek 1871-ben, Newman nem javasolta a részvételt: „A fiúk országból kiutazásának eldöntése nem tartozik egy pedagógus hatáskörébe... A diákoknak nincs helyük a politikai demonstrációkon." (Newman, 1970, pp. 160-161) Végül az iskola az eseményen nem képviseltette magát. A fiúkkal való kapcsolat lehetőséget adott Newman számára, hogy figyelemmel kísérje oktatásukat, nevelésüket, és lehetősége volt észrevételeket tenni mindezeken a területeken.

Newman számára a legtöbb szorongást okozó problémák három kategóriába sorolhatók: azok az általános jellegű nehézségek, amelyek többé-kevésbé bármelyik iskola működtetésekor jelentkeznek; a pénzügyi korlátok; valamint az emberi erőforrások elégtelensége. Ezek közül a finanszírozás jelentett állandó gondot. Gyakorlatilag bármely iskolának lehetnek pénzügyi nehézségei, de az épületek átalakításának kiadásai, a fizetések és a fenntartás általános költségei okot adtak az aggodalomra. Ez az iskola sem volt kivétel.

Edward Bellasis-nek szóló levelében ezt írta Newman: „Éppen most ellenőriztük a könyvelésünket. 1858 Húsvét óta több mint 12900 fontot költöttünk el..." (Newman, 1970, pp. 160-161) Majd ezt követően részletesen levezette a barátjának számításait. Egy olyan ember számára, mint Newman, aki pénzügyekben is jártas volt, ez valóban aggasztó lehetett, még akkor is, ha aritmetikája téves volt.

1862 júliusában Newman egy levelében arról panaszkodik, hogy nincs elég pénzük számláik kielégítésére. „Az igazság az, hogy az iskola nem tartható fenn az éves 80 fontos befizetésekkel. Ha a fiúk száma százra nőne, akkor létrehozhatnánák egy pénzalapot... de jelenleg máról holnapra élünk." (Newman, 1970, pp. 160-161) Az anyagi problémák megoldására két út mutatkozott, a tanulók számának növelése és a tan- és a szállásdíj emelése. 
Úgy tűnik, hogy a finanszírozási nehézségek okának egy része a pazarlásból (biztosan nem Newman részéről) és a rossz könyvelésből adódott. Nem sokkal azután, hogy a könyvelést átvette Fr. Darnell-től, gyorsan kijöttek az adósságból, és még némi nyereség is keletkezett. Newman nagy örömmel számolt be az 1862-es auditról: „Úgy gondoljuk, hogy nincs hiba. Ez évi 600 font nyereséget jelentene." (Newman, 1970, p. 260) Az ilyen sikerek általában rövid életűek voltak, és váltakoztak az elkeseredettség időszakaival.

A norfolki herceg, az iskola öregdiákja, egy másik nagylelkű jótevő volt, aki anyagilag segítette az iskolát ingatlanok bérlésével és földvásárlással. 1873-ra azonban az intézmény ismét eladósodott, mert a kintlévőségek érvényesítése nem járt eredménnyel. Az egyik visszatérő probléma az volt, hogy a szülők egy része nem fizette be a díjakat határidőre. Newman az 1880-as évek elejére belefáradt a fennmaradás örökös küzdelmébe.

Más problémák is felmerültek, de nem jelentettek akkora állandó terhet, mint a pénzügyi nehézségek. Többségük megoldható gond volt, amelyek nem okoztak súlyos válságot az iskola vezetésének. 1865-ben történt egy lopás (az iskola megnyitása óta csak a második), amelyet Newman a maga módján kezelt. Newman Edward Bellasis-nak írt levelében utalt az ügyre: „Körülbelül három hét telt el azóta, hogy a tulajdonos utoljára látta a pénzét... Nem sejtettük, hogy ki a fiú; ... azt mondtuk, hogy az iskola minden diákjának a gyóntatójához kell fordulnia ebben az ügyben; és ha ... a pénzt (titokban) egy meghatározott helyre teszik, akkor nem beszélünk többet róla." (Newman, 1972, pp. 111-112) Talán nem meglepő, hogy a pénz megkerült.

A többi katolikus iskolával való versengés is nehézséget okozott. „...nyilvánvalóan a „Beaumont Lodge (a jezsuiták iskolája) kiszorított minket.” (Newman, 1970, p. 493) Más problémák kevésbé voltak általánosak, és tükrözik az iskolához és személyesen Newmanhoz való viszonyulást. Előfordult, hogy panasz érkezett a helyi anglikán segédlelkésztől a fiúk vasárnapi krikettezése miatt. Newman elnézést kért. Kisebb aggályok merültek fel a diákok tanáraiknál való elszállásolásával, a vakáció alatti iskolai tartózkodásukkal, külföldi fiúk befogadásával kapcsolatban, és az esetenként megjelenő járványokkor. Ezen felül még folytatódtak azok a Newmanről szóló pletykák, amelyek egy oxfordi katolikus felsőoktatási intézmény létrehozására irányuló javaslatról és ezzel összefüggésben az iskoláról szóltak. Ez tulajdonképpen inkább Newman kritikája lehetett. Az anglikán egyház egyeduralma a felsőoktatásban megtört, amikor 1828-ban megalapították a „University College London”-t, amely teljesen szekularizált intézmény volt. Newmant azzal is vádolták, hogy fiatalembereket készített fel, hogy Oxfordba menjenek, ahol aztán hitük elkerülhetetlenül elveszett. Ez a vád számára nem kevés fájdalmat okozott és sok gonddal járt, különösen, amikor magas római körökben erről kérdezték. Newman ezeket a vádakat határozottan cáfolta. A birminghami püspök 1867. október 13-ai főpásztori utasításainak megfelelően nem készített fel diákokat oxfordi és cambridge-i vizsgákra.

Barnabo bíborosnak erős ellenérzései voltak Newman-nel szemben ebben a kérdésben. A valódi oka ennek az volt, hogy nem tudott konvertitákat „felmutatni”, ahogy ez Manning és Faber bíborosoknak sikerült. Oxford csupán ürügy volt. Az ügy komolysága miatt Newman kénytelen volt elküldeni Rómába Ambrose Szent Jánost, hogy fellépjen a védelmében, mivel személyesen ezt képtelen volt megtenni. Newman erről így vallott a folyóiratában (The Rambler): „Attól az időtől kezdve mindenféle vádat és rágalmat füztek 
a nevemhez. És amióta elkezdtük az iskolát, az intézménnyel szembeni ellenérzések növekedtek... Érzékelem az ellenszenvet és a bizalmatlanságot ... mert (minden látszat szerint) sikerrel jártak a befolyásom és hasznosságom lerombolásában. Olyan személyek, akik nyilvánvalóan rám tekintenének, konvertiták, akik hozzám fordulnának ... megállnak valamilyen ellenem mondott súlytalan vagy barátságtalan szavak miatt." (Tristram, 1957, pp. 256-257)

Newman nem vallott kudarcot, nem térítette el céljaitól a rosszindulatú kritika. Ez nemcsak a befolyását csökkentette, hanem ráébresztette arra is, hogy munkája a fiúk oktatására jelentéktelen hatással volt. Az olyan ügyek, mint az apró lopások, a vasárnapi krikett, sőt a gyűlölködő és káros pletykák is irritáló hatásúak voltak, de ennél többet nem jelentettek. Ezek nem terelték el attól, hogy megtegye, amit szükségesnek tart, hogy jó közoktatást biztosítson a katolikus szülők gyerekei számára. Bár Newman alapította az iskolát, felelősséget érzett iránta és felügyelte is, de soha nem volt annak igazgatója. Ellenőrizte a személyzet felvételét és esetenként elbocsátását. Ez nem volt vitatott terület, az iskolát és Newmant is büszkeséggel töltötte el, hogy jól ismert embereket tudott megnyerni a tanításnak.

Thomas Arnold iskolához való 1862-es csatlakozása rövid és nem zökkenőmentes kapcsolat volt. A kezdeti boldogság után 1863 végére Arnold beteg lett. Gyermekei, akik Westmorlandben tanultak, bentlakóként érkeztek volna az iskolába. Newman azonban vonakodott befogadni őket, mivel attól tartott, hogy fertőzést hozhatnak magukkal. Ez a tény és Newman javaslata, hogy 55 fontot vonjanak le Arnold 133 fontos fizetéséből távolléte kompenzációjaként, megrontotta a kapcsolatukat. Bár a kilátásba helyezett következmények egyike sem realizálódott, a barátságuk nem javult. Arnold, akinek hitében voltak megingásai, 1864-ben elhagyta az iskolát. Rajta kívül az egyetlen híresség, aki tanított az iskolában, Gerard Manley Hopkins volt, aki 1867-ben csatlakozott.

1870-ben az egyik tanárt kémként letartóztatták, amikor Európában tartózkodott, azonban rövidesen elengedték. Newmannek 1879-ben el kellett bocsátania az egyik pedagógust. Harding, - akiről Newman azt írta, hogy sok jó tulajdonsággal rendelkezik, de nem elég fegyelmezett, - Newman nemtetszésének ellenére „angolosan távozott”. Így azonnal értesítette Hardling-ot a következőkről: „Az atyák nagyon meglepődtek szabadság nélküli távozásán... és arra is emlékezzen, hogy Karácsonykor is így volt távol. Tekintsük tehát úgy, hogy a velünk fennálló kapcsolata megszűnt" (Newman, 1973, p. 67)

Egy másik ügy azonban nagyobb fájdalmat okozott Newman számára, amellyel 186162 telén sok időt töltött. Nagy felfordulást okozott az iskola és az oratórium közösségének életében Newman összetűzése Fr. Darnellel, amelynek tetőpontját Darnell lemondása és eltávolítása jelentette 1862 júliusában, de terjedelmi okok miatt ennek részleteire most nem térek ki.

Egy meghatározó kérdés, amely mindig is Newman és az Oratóriumi Iskolába járó fiúk szüleinek szeme előtt lebegett az volt, hogy mi lesz a tanulókkal az iskola elvégzését követően. Oxfordot és Cambridge-t, a már megvalósult kisebb reformok mellett is, bűnös helyeknek tekintették, amelyek veszélyeztetik a diákok Newman által megalapozott hitét. A preferált irány egy katolikus egyetem alapítása volt, amely lehetőséget biztosíthatna az oktatásukra, és megvédené őket a „romlástól”. Ismét bizalmatlanság és félreértés jelent 
meg Newman indítékaival és álláspontjával szemben az ellenzők részéről. Manning Newman-t egy ilyen projekt fő támogatójaként mutatta be, holott nem volt az, de korának vezető katolikus angol értelmiségieként, jól ismerve a felsőoktatás minden aspektusát, magától értődően tanácsadójává vált azoknak, akik ezt az elképzelést támogatták.

Newman jogosan aggódott iskolája diákjainak jövője miatt. A katolikusok felsőfokú tanulmányainak megoldása minden bizonnyal őt is aggasztotta. Különböző projektekben vett részt, hogy földet vásároljon Oxfordban egy ilyen intézmény számára, de James Spencer Northcote-nak írt levelében azonban világossá tette érzéseit: „Nem javasolnék ... egy katolikus egyetemet Oxfordban ... jelen pillanatban vitát jelentene...” (Newman, 1970, p. 423) Engedelmes katolikusként Newman elkötelezte magát a Szentszék politikájának elfogadása mellett.

Természetes, hogy az évek előrehaladtával még egy energiával és általában jó egészséggel megáldott ember is kénytelen lassítani tevékenységének ütemén. Ezt Newman is megtette, de továbbra is részt vett az iskola munkájában és felügyelte annak működését. Folytatta az intézmény finanszírozásáról való gondoskodást és a várható jótevők „nyaggatását”, mint tette ezt például a béketűrő és nagylelkű norfolki herceg esetében. Mindig szem előtt tartotta, hogy példát kell mutatnia másoknak, így felajánlotta a könyvei után járó jogdíjakból származó bevételeit az iskola javára (Newman, 1976).

Tevékenységük valóban sikeres volt, mindannak ellenére, hogy sok akadályt le kellett küzdeni, de ezek Newman idős korában igen vigasztalóan hatottak rá. Felmerült a kérdés másokban, de talán magában Newman-ben is, hogy alakul az iskola sorsa halálát követően. A norfolki herceg is aggódott az intézmény jövője miatt, így fogalmazott a Newmannek 1882-ben írt egyik levelében: „Ami az iskola feladásának gondolatát illeti, még soha egyik atyánál sem merült fel. Az angolok szerint joguk van morogni és kritizálni ... de óriás csapás lenne számunkra az iskola bezárása ..." (Newman, 1976, pp. 53-54)

\section{Összegzés}

Newman 1890. augusztus 11-én halt meg. Egyik írásában felsorolja a négy legfontosabb dolgot, amit Isten tett érte, és amiért a leghálásabb. Ezek között szerepelt az oratóriumi iskola megalapítása is. Konklúzióként levonható, hogy Newman az általa alapított közösség fáradhatatlan elöljárója volt, hogy az oratóriumi iskola másfajta elfoglaltságot is biztosított számára, nevezetesen az idősebb fiúk vizsgára való felkészítését, az éves színdarabok megszervezését és alkalmanként valláserkölcsi iránymutatást is.

Newman a személlyel való párbeszédben nevelte a reábízottakat. Erőteljes hangsúlyt helyezett az oktatás melletti jellemgyarapítás folyamatának harmonikus összehangolására. Ő a nevelés fogalmán jellemformálást értett elsősorban, vallási kötődéssel, látszólag kifejezett „haszonélvezet” nélkül.

XVI. Benedek pápa Newman boldoggá avatási laudációjában a következőt mondta: „Newman életében megvalósította e mélységesen emberi felfogását Birmingham népének odaadó gondozásában azokban az években, amelyeket az általa alapított Oratóriumban töltött ... Olyan nevelési környezetet igyekezett megvalósítani, amelyben az értelem képzése, az erkölcsi fegyelmezettség és vallásos elköteleződés összekapcsolódnak egymással." (Nemeshegyi, 2010, pp. 34-35) 


\section{Irodalomjegyzék}

Ashton, R. (2008. május 24). Oxford Dictionary of National Biography. Society for the Diffusion of Useful Knowledge.

https://www.oxforddnb.com/view/10.1093/ref:odnb/9780198614128.001.0001/odnb-

9780198614128-e-59807 (Letöltés dátuma: 2021. március 11.)

Conzemius, V. (1991). John Henry Newman bíboros halálának 100. évfordulójára. Mérleg, 27 (3), 305-312.

CulIer, A. D. (1955). The Imperial Intellect, a study of Newman's educational ideal. Yale University Press.

Nemeshegyi, P. (2010). John Henry Newman vándorútja. Szent István Társulat.

Newman, J.H. (1968). The Letters and Diaries of John Henry Newman. Vol. 18. (C. S. Dessain, Ed.). Thomas Nelson and Sons.

Newman, J.H. (1969). The Letters and Diaries of John Henry Newman. Vol. 19. (C. S. Dessain, Ed.). Oxford University Press.

Newman, J.H. (1970). The Letters and Diaries of John Henry Newman. Vol. 20. (C. S. Dessain, Ed.). Thomas Nelson and Sons.

Newman, J.H. (1972). The Letters and Diaries of John Henry Newman. Vol. 22. (C. S. Dessain, Ed.). Thomas Nelson and Sons.

Newman, J.H. (1973). The Letters and Diaries of John Henry Newman. Vol. 24. (C. S. Dessain \& Gornall, T. Eds.). Oxford University Press.

Newman, J.H. (1976). The Letters and Diaries of John Henry Newman. Vol. 30. (C. S. Dessain, Ed.). Clarendon Press.

Newman, J. H. (Saglic, M. J. előszavával és jegyzeteivel). (1982). The Idea of a University. University Notre Dame Press.

Sík, S. (1955). Newman - Az ember és az imádkozó. Vigilia, 20 (7), 339-349.

Stockley, W. F. D. (1922). Education According to Newman. The Month, Vol. 148

The Oratory School. (dátum nélk.). Coeducation at The Oratory.

https://www.oratory.co.uk/about/coeducation (Letöltés dátuma: 2021. március 11.)

Tristram, H. (Ed.). (1957). John Henry Newman, Autobiographical Writings. Sheed and Ward.

Várnagy, P. (2014). J. H. Newman pedagógiája a "The Idea of a University" tükrében. PTE FEEK.

Vértesaljai, L. (2019. október 12). Vatican News. John Henry Newman bíboros, az Igazság apostola.

https://www.vaticannews.va/hu/papa/news/2019-10/newman-biboros-igazsag-apostol-szentte-avatasanglikan-megteres.html (Letöltés dátuma: 2021. március 11.)

Ward, W. (1913). The Life of John Henry Cardinal Newman Based on his Private Journals and Correspondence. Longmans. 